\title{
Early action on Paris Agreement allows for more time to change energy systems
}

\author{
Heleen L. van Soest ${ }^{1,2}$ - Harmen Sytze de Boer ${ }^{1,2}$ • \\ Mark Roelfsema $^{1} \cdot$ Michel G.J. den Elzen ${ }^{1}$ • \\ Annemiek Admiraal ${ }^{1}$ - Detlef P. van Vuuren ${ }^{1,2}$. \\ Andries F. Hof ${ }^{1,2}$ - Maarten van den Berg ${ }^{1,2}$. \\ Mathijs J.H.M. Harmsen ${ }^{1,2}$ • David E.H.J. Gernaat ${ }^{1,2}$ • \\ Nicklas Forsell ${ }^{3}$
}

Received: 7 June 2016 / Accepted: 7 July 2017 / Published online: 24 July 2017

(C) The Author(s) 2017. This article is an open access publication

\begin{abstract}
The IMAGE integrated assessment model was used to develop a set of scenarios to evaluate the Nationally Determined Contributions (NDCs) submitted by Parties under the Paris Agreement. The scenarios project emissions and energy system changes under (i) current policies, (ii) implementation of the NDCs, and (iii) various trajectories to a radiative forcing level of $2.8 \mathrm{~W} / \mathrm{m}^{2}$ in 2100 , which gives a probability of about two thirds to limit warming to below $2{ }^{\circ} \mathrm{C}$. The scenarios show that a cost-optimal pathway from 2020 onwards towards $2.8 \mathrm{~W} / \mathrm{m}^{2}$ leads to a global greenhouse gas emission level of 38 gigatonne $\mathrm{CO}_{2}$ equivalent $\left(\mathrm{GtCO}_{2} \mathrm{eq}\right)$ by 2030 , equal to a reduction of $20 \%$ compared to the 2010 level. The NDCs are projected to lead to 2030 emission levels of $50 \mathrm{GtCO}_{2}$ eq, which is still an increase compared to the 2010 level. A scenario that achieves the $2.8 \mathrm{~W} / \mathrm{m}^{2}$ forcing level in 2100 from the 2030 NDC level requires more rapid transitions after 2030 to meet the forcing target. It shows an annual reduction rate in greenhouse gas emissions of $4.7 \%$ between 2030 and 2050, rapidly phasing out unabated coal-fired power plant capacity, more rapid scale-up of low-carbon energy, and higher mitigation costs. A bridge scenario shows that enhancing the ambition level of NDCs before 2030 allows for a smoother energy system transition, with average annual
\end{abstract}

Electronic supplementary material The online version of this article (doi:10.1007/s10584-017-2027-8) contains supplementary material, which is available to authorized users.

Heleen L. van Soest

Heleen.vanSoest@pbl.nl

1 PBL Netherlands Environmental Assessment Agency, P.O. Box 30314, 2500 GH The Hague, The Netherlands

2 Copernicus Institute of Sustainable Development, Utrecht University, P.O. Box 80.115, 3508 TC Utrecht, The Netherlands

3 International Institute for Applied Systems Analysis, Schlossplatz 1, 2361 Laxenburg, Austria 
emission reduction rates of $4.5 \%$ between 2030 and 2050, and more time to phase out coal capacity.

\section{Introduction}

All Parties to the United Nations Framework Convention on Climate Change (UNFCCC) in Paris in December 2015 agreed to reduce global greenhouse gas (GHG) emissions to keep the increase in global mean temperature to well below $2{ }^{\circ} \mathrm{C}$ relative to pre-industrial levels, and furthermore to pursue efforts to limit this increase further to $1.5{ }^{\circ} \mathrm{C}$ (UNFCCC 2015a). Outlining the contribution to these GHG emission reductions, 161 Parties (representing over 97\% of global GHG emissions in 2012) had submitted post-2020 Intended Nationally Determined Contributions (INDCs) to the UNFCCC by February 2016 (UNFCCC 2015b). The Paris Agreement entered into force on 4 November 2016, after it had been ratified by the required number of countries. ${ }^{1}$ This re-asserts the process that started earlier. By 2009 in Copenhagen, countries had agreed to implement non-binding emission reduction proposals (pledges) for 2020 (UNFCCC 2009). Many countries representing about 75\% of global 2010 emissions (UNEP 2014) had submitted reduction plans or pledges, which were later anchored in the Cancún Agreements (UNFCCC 2010).

The effect of the 2020 pledges on global emissions in that year has been analysed in various studies (e.g. Fekete et al. 2013; Hof et al. 2013; Kriegler et al. 2013a) and summarised in the UNEP Gap reports (UNEP 2013, 2014). In addition, several studies analysed whether countries are on track to meet their pledges and concluded that current policies are projected to result in global 2020 emission levels at the upper limit of the emission range resulting from the pledges (Climate Action Tracker 2015; den Elzen et al. 2015; Roelfsema et al. 2014; UNEP 2015). In a next step, both the pledges and current policies were found to lead to higher 2020 global emissions than cost-optimal $2{ }^{\circ} \mathrm{C}$ pathways (e.g. Jakob et al. 2012; Kriegler et al. 2013a, 2013b; Kriegler et al. 2014a, 2014b; Luderer et al. 2013a, 2013b; Riahi et al. 2013; Rogelj et al. 2013a, 2013b; van Vliet et al. 2012). However, these studies also concluded that achieving the $2{ }^{\circ} \mathrm{C}$ target with a likely chance ( $>66 \%$ probability) would still be technically feasible under delayed mitigation scenarios consistent with the pledges, i.e. only modest emission reductions up to 2020 and deep reductions thereafter.

Similar questions now apply to the NDCs for 2030. Recently, UNEP (2015) assessed the 2030 global emission levels consistent with meeting $2{ }^{\circ} \mathrm{C}$ with a likely chance based on existing delayed scenarios starting with cost-effective reduction after 2020. Several studies (e.g. den Elzen et al. 2016; Fawcett et al. 2015; Rogelj et al. 2016; Vandyck et al. 2016) concluded that the global emission level in 2030 resulting from the NDCs is considerably higher than the emission level of a cost-effective pathway to keep the global temperature increase below $2{ }^{\circ} \mathrm{C}$ (Clarke et al. 2014; UNEP 2015). This gap was acknowledged in the Paris Agreement and Parties agreed to submit new or updated national climate plans by 2020 (known as nationally determined contributions, so-called NDCs). The Agreement also established a process in which Parties put forward more ambitious NDCs every 5 years.

\footnotetext{
${ }^{1}$ By 10 April 2017, 143 of 197 Parties to the Convention had ratified, representing about $83 \%$ of global greenhouse emissions. With each country's ratification, its INDC becomes an NDC, which we use throughout this paper.
} 
The effect of the NDCs and enhanced mitigation ambition needs to be assessed in light of this agreement. Such analyses could build on earlier studies that analysed the long-term impacts of short-term policies (e.g. Riahi et al. 2013) and could include the most recent assessments of the outcomes of the NDCs (e.g. Fawcett et al. 2015, Vandyck et al. 2016).

Our study assessed the long-term impacts of the NDCs and whether the internationally agreed $2{ }^{\circ} \mathrm{C}$ target can still be achieved in mitigation scenarios taking into account the NDCs. We also assessed the implications of enhancing the mitigation ambition of the NDCs, focusing on long-term effects on energy and land-use systems and the level of mitigation costs in achieving $2{ }^{\circ} \mathrm{C}$ emission pathways. This study goes beyond existing literature by building upon a detailed assessment of existing national policies, 2020 pledges and NDCs (i.e. as assessed by den Elzen et al. 2016). This consideration of current policies and the most recent international pledges and NDCs enables new insights into 2020 and 2030 emissions and energy projections and into how differences in timing and level of ambition of climate policy affect transition pathways.

\section{Methods}

\subsection{Model framework}

The scenarios in this study were analysed using the IMAGE integrated assessment modelling framework (Stehfest et al. 2014; van den Berg et al. 2015). The IMAGE framework is a simulation model with a recursive-dynamic (myopic) solution method, a partial equilibrium solution concept (price elastic demand), 26 world regions, and five economic sectors. This framework consists of a set of soft-linked models, ${ }^{2}$ including a detailed energy-system model (TIMER), a land-use model (IMAGE land), and a global climate policy model (FAIR).

TIMER describes the long-term energy demand and production for different end-use and supply sectors. One hundred eighty energy end-use technologies and 54 energy conversion technologies are used, and substitution among technologies is described using the multinomial logit formulation. For most innovative technologies, technological progress is endogenously formulated on the basis of learning by doing. Inertia in capital stocks is included in the electricity generation sector, using a vintage formulation for the autonomous increase in energy efficiency. Retrofitting in the electricity sector is not simulated. The IMAGE land model looks into the long-term dynamics of the agricultural system and consequences for global land-cover. The agricultural system is described for seven agricultural crops and five animal product types.

Information of both baseline and mitigation options in the energy and land-use systems is forwarded to the climate policy model FAIR. The model is able to optimise global greenhouse gas emission pathways over time and across sectors and gases to achieve emission levels or climate targets at lowest cost, based on cumulative discounted abatement costs (using a $5 \%$ discount rate). For this purpose, the optimisation procedure employs a nonlinear, constrained, optimisation algorithm (the MATLAB FMINCON procedure; for further details, see van den Berg et al. 2015). The abatement costs in FAIR depend on baseline emissions and time-, baseline-, and regional-specific marginal abatement cost (MAC) curves from the other IMAGE framework models. Subsequently, the information on mitigation action (mostly carbon prices)

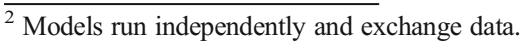


is fed back from FAIR to the TIMER and IMAGE land models (in response, TIMER will for instance invest more in renewable energy).

For energy- and industry-related $\mathrm{CO}_{2}$ emissions, MAC curves are determined by imposing a carbon price in the TIMER energy model and recording the induced reduction in $\mathrm{CO}_{2}$ emissions. In order to capture the time- and pathway-dependent dynamics (due to technology learning and inertia related to capital-turnover rates) of the underlying TIMER model, MAC curves are derived for different reduction pathways and scaled in the FAIR model based on the actual implementation (van Vliet et al. 2012). For non- $\mathrm{CO}_{2}$ emissions, the agriculture-related emissions from IMAGE land are combined with MAC curves based on Lucas et al. (2007) using updates of U.S. EPA (2013), Harnisch et al. (2009), and Schwarz et al. (2011). Given the detailed analysis of current policies and NDCs for land-use change and forestry (LULUCF), $\mathrm{CO}_{2}$ emissions by the GLOBIOM/G4M team were used here instead of using IMAGE land, in combination with the response curves from the GLOBIOM/G4M models (Havlík et al. 2014; Böttcher et al. 2011; Kindermann et al. 2008) (see also Online Resources - Supplementary text). For calculating $\mathrm{CO}_{2}$-equivalent emissions, 100-year Global Warming Potentials from IPCC AR4 are used (GHGs covered are $\mathrm{CO}_{2}, \mathrm{CH}_{4}, \mathrm{~N}_{2} \mathrm{O}, \mathrm{PFCs}, \mathrm{HFCs}, \mathrm{SF}_{6}$ ). The total abatement costs for each future year are calculated by FAIR as the total area under the MAC curves (TIMER-derived MACs, non- $\mathrm{CO}_{2}$ MACs, and G4M land-use change MACs) at the determined regionally and time-specific carbon price levels.

\subsection{Scenarios}

The starting point for the calculations was the SSP2 (Shared Socioeconomic Pathways) scenario and its storyline as implemented in IMAGE (as described in detail in van Vuuren et al. 2016). The GDP and population projections were based on median assumptions, with population stabilising at 9 billion by 2050. Based on this scenario, a set of policy relevant scenarios was developed (see Table 1).

The current policies scenario was derived from the original SSP2 baseline by introducing explicit policy measures (Section 2.2.1). Subsequently, the two NDC scenarios were implemented by introducing a carbon price in order to meet the NDC goals of different countries (Section 2.2.2). In response to the price, measures are introduced in a cost-effective way throughout the model (i.e. in the energy and land-use system). Finally, three long-term climate policy scenarios were implemented meeting a long-term radiative forcing target consistent with staying below $2{ }^{\circ} \mathrm{C}$, using a global carbon price (Section 2.2.3). These long-term policy scenarios start from different years (i.e. 2020, 2025, and 2030, as described below). Our study focused on the results for the 2010-2050 period, but the scenarios were developed for the full century.

\subsubsection{Current policies scenario}

The current policies scenario includes current climate and energy policies of major emitting countries, such as the assumed implementation of renewable energy share or capacity targets, power plant standards, fuel efficiency standards for cars, and carbon prices (den Elzen et al. 2015; Roelfsema et al. 2014). Carbon prices mainly impact the energy and industry sectors, by changing the price for energy carriers and as such influencing the choice for technologies in the multinomial logit equation, making low-carbon technologies relatively cheaper and highcarbon technologies more expensive. The measures are described in detail in Table S.1 (Online Resource). After the policy target year, the policy driver was discontinued. Policies may have a 


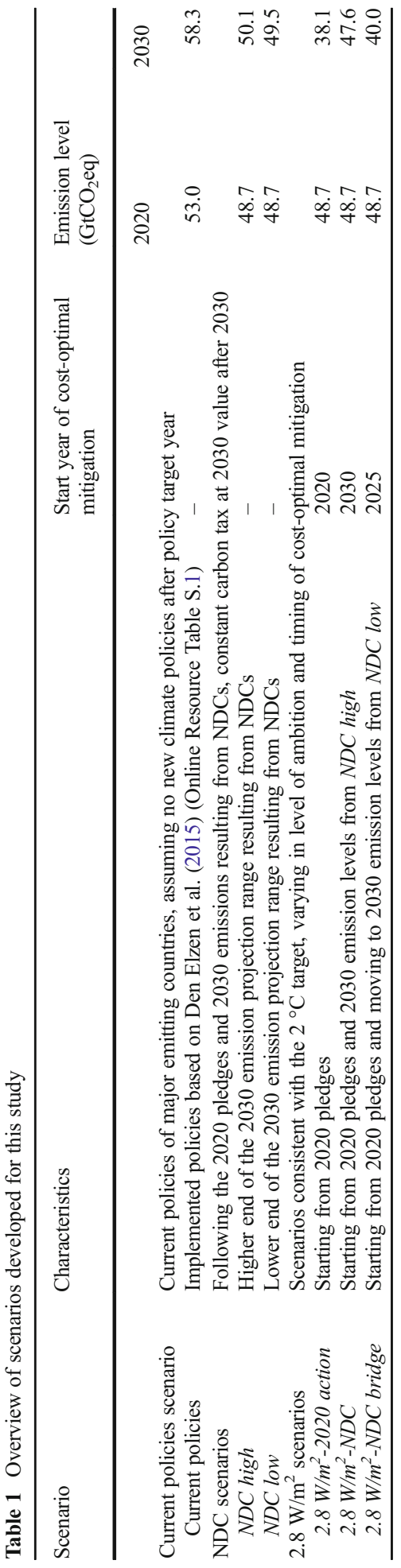


long-term effect through the induced technology learning effects (e.g. by additionally installed renewable energy technologies compared to the SSP2 baseline). LULUCF policies were implemented in the GLOBIOM/G4M model framework. The 2020 pledges were not included in this scenario, resulting in greenhouse gas emission projections deviating from the NDC and mitigation scenarios from 2010 onwards.

\subsubsection{NDC scenarios}

The NDC high and low scenarios start from emission levels in 2020 resulting from current policies and 2020 pledges, and 2030 emission levels resulting from the full implementation of the NDCs (based on den Elzen et al. 2016, see Online Resource Table S.1). However, we assumed that Kazakhstan, the Russian Federation, Turkey and Ukraine followed the current policies scenario, as it resulted in lower emissions than their respective NDCs (see also den Elzen et al. 2016). If current policies (Section 2.2.1) were found to be insufficient to reach the NDC targets, a carbon price was introduced to reach the emission levels resulting from the implementation of the 2020 pledge and the NDCs. The regional carbon prices that emerged under the NDCs in 2030 were kept constant thereafter, implying that emissions remain below the original current policies scenario. For model regions in which not all countries have a pledge or an NDC, the absolute emission reductions in 2020 and 2030 resulting from the country pledges and NDCs within the region were subtracted from the BAU. The emission projection resulting from South Korea's NDC was combined with BAU emission projections for North Korea because the IMAGE model has one Korea region. Similarly, the emission projections resulting from Australia's and New Zealand's NDCs were added to the Oceania region of IMAGE. Finally, Brazil's indicative 2030 target was used, while the USA's NDC for 2025 was extended to 2030 by linearly interpolating between the 2025 NDC and the USA's long-term emission reduction target for 2050.

NDC high The NDC high scenario represents the upper end of the range of emission levels expected to result from NDC targets. In addition to unconditional NDCs, some countries also have stronger targets, conditional on financial support. In the NDC high scenario, we considered only unconditional NDCs and the least ambitious of NDC emission target ranges, where applicable. Next to Kazakhstan, the Russian Federation, Turkey and Ukraine, India followed the current policies scenario, as it resulted in lower emissions than its NDC. The NDCs for all other countries were assumed to be achieved domestically by not allowing international trade of emission credits until 2030.

NDC low The NDC low scenario represents the lower end of the range of NDC emission levels. In addition to unconditional NDCs, we also considered conditional NDCs in NDC low. Where countries provided emission target ranges, the most ambitious value was taken. For India, NDC low followed the current policies scenario (which satisfied the intensity target as stated in the NDC) like the NDC high scenario, but in addition included the effect of the renewable energy target.

\subsubsection{Mitigation scenarios consistent with the $2{ }^{\circ} \mathrm{C}$ climate target}

The three long-term mitigation scenarios start from the emission levels in 2020, 2025, and 2030 based on the NDC scenarios. The long-term climate target of the various scenarios in this 
group was set to $2.8 \mathrm{~W} / \mathrm{m}^{2}$ in 2100 . This value is within the "likely below $2{ }^{\circ} \mathrm{C}$ " range from IPCC: $2.3-2.9 \mathrm{~W} / \mathrm{m}^{2}$ (Clarke et al. 2014). The $2.8 \mathrm{~W} / \mathrm{m}^{2}$ scenarios have a chance of about two third of staying below $2{ }^{\circ} \mathrm{C}$ at the end of the century, allowing for a lower chance or a temperature overshoot before. We assumed this to be consistent with the Paris Agreement's goal to limit global warming to well below $2{ }^{\circ} \mathrm{C}$. Achieving more ambitious targets, e.g. staying below $2{ }^{\circ} \mathrm{C}$ with a higher likelihood, is difficult in the model given the delay assumed in the NDC high scenario. The mitigation scenarios assumed full availability of mitigation technologies, meaning the model was allowed to use negative emission technology, specifically biomass with CCS, reforestation, and afforestation.

2.8 W/m $\mathbf{m}^{2}-2020$ action Up until 2020, the pledge assumptions determined the emission pathways. After 2020, a cost-optimal emission reduction pathway towards the long-term climate target by means of a global carbon price was implemented. In the $2.8 \mathrm{~W} / \mathrm{m}^{2}-2020$ action scenario, Brazil, India, Japan, Russia, and Ukraine followed the current policies scenario, because it resulted in lower emissions than the 2020 pledges.

2.8 W/m $\mathbf{m}$-NDC To analyse the transition from the unconditional NDCs in 2030 to the $2.8 \mathrm{~W} / \mathrm{m}^{2}$ climate target, the $2.8 \mathrm{~W} / \mathrm{m}^{2}-N D C$ scenario started from the 2030 emission levels of the NDC high scenario. International trade was not allowed until 2030, reflecting the domestic nature of the unconditional NDCs. After 2030, a cost-optimal emission reduction pathway by means of a global carbon price was implemented. Some unconditional NDCs are overachieved in this scenario due to mitigation effort starting in 2030 (a result of TIMER using projected future carbon prices to steer investment decisions; de Boer and van Vuuren 2017).

2.8 W/m $\mathbf{m}^{2}$-NDC bridge To study the implications of strengthening the ambition level of NDCs, the $2.8 \mathrm{~W} / \mathrm{m}^{2}$-NDC bridge scenario followed the emission pathway of the NDC low scenario up to 2025 , effectively starting in 2020 from the 2020 pledges moving towards the 2030 emission levels of the NDC low scenario. However, after 2025, a cost-optimal emission reduction pathway by means of a global carbon price was implemented.

\section{Results}

\subsection{Global greenhouse gas emissions}

We focus the discussion of results on the current policies scenario and the $2.8 \mathrm{~W} / \mathrm{m}^{2}$ scenarios. Under the current policies scenario, global emission levels are projected to increase between 2020 and 2050 (Fig. 1, and Online Resource Fig. S.1 for projections through 2100). In contrast, implementation of NDCs is projected to result in a peak in global GHG emissions in 2030. By 2030, GHG emissions reduce by 14\% (NDC high) to $15 \%$ (NDC low) compared to the current policies scenario. Between 2030 and 2050, emissions stabilise due to an autonomously decreasing GHG intensity of the economy. Enhancing NDC ambition as in the $2.8 \mathrm{~W} / \mathrm{m}^{2}-N D C$ bridge scenario resulted in a GHG emission reduction of $31 \%$ by 2030 relative to the current policies scenario. GHG emissions are projected to be approximately $38 \mathrm{GtCO}_{2}$ eq in 2030 under the $2.8 \mathrm{~W} / \mathrm{m}^{2}-2020$ action scenario, a reduction of $20 \%$ on 2010 levels. In contrast, the NDCs are projected to lead 


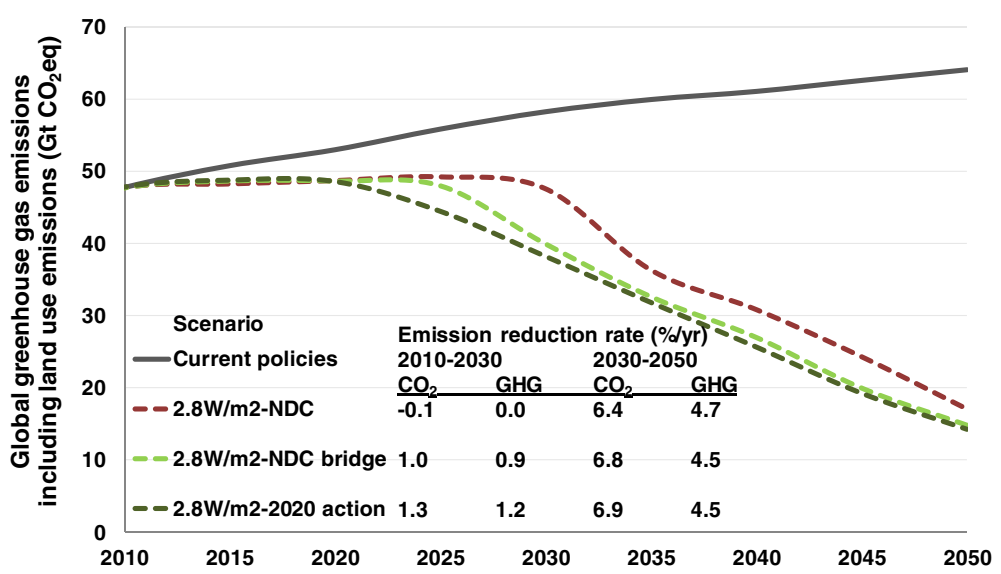

Fig. 1 Global GHG emissions ( $\mathrm{GtCO}_{2} \mathrm{eq} /$ year) between 2010 and 2050, including $\mathrm{CO}_{2}$ emissions from land use, under the current policies scenario (solid line), and the $2.8 \mathrm{~W} / \mathrm{m}^{2}$ scenarios $\left(2.8 \mathrm{~W} / \mathrm{m}^{2}-\mathrm{NDC}, 2.8 \mathrm{~W} / \mathrm{m}^{2}-\mathrm{NDC}\right.$ bridge and $2.8 \mathrm{~W} / \mathrm{m}^{2}-2020$ action; dashed lines)

to 2030 emission levels of approximately $50 \mathrm{GtCO}_{2}$ eq, an increase of $5 \%$ on 2010 levels (see Online Resource Fig. S1).

GHG emission reductions between 2010 and 2050 in the three $2.8 \mathrm{~W} / \mathrm{m}^{2}$ scenarios range from 64 to $70 \%$ (including LULUCF). In the $2.8 \mathrm{~W} / \mathrm{m}^{2}-N D C$ scenario, GHG emissions are projected to be reduced from $47.6 \mathrm{GtCO}_{2}$ eq in 2030 to $17.1 \mathrm{GtCO}_{2}$ eq in 2050 . This required average rates of GHG emission reduction of $4.7 \%$ year between 2030 and 2050. The $2.8 \mathrm{~W} / \mathrm{m}^{2}-N D C$ bridge scenario showed a similar GHG emission level by 2050 (14.8 $\left.\mathrm{GtCO}_{2} \mathrm{eq}\right)$, but the reduction rate was lower (4.5\%/year) as emissions in 2030 are projected to be $40.0 \mathrm{GtCO}_{2}$ eq. The $2.8 \mathrm{~W} / \mathrm{m}^{2}-N D C$ scenario also showed larger emission reductions after 2050 to compensate for the extra emissions before 2050 (Fig. S.1).

Figure 2 shows global sectoral emissions until 2050. Under the current policies scenario, emissions in most sectors are projected to remain constant or increase between 2010 and 2050, except for LULUCF emissions. In contrast, emissions are projected to decrease strongly under the $2.8 \mathrm{~W} / \mathrm{m}^{2}$ scenarios. Total emissions are projected to be reduced by $18 \%$ in the $2.8 \mathrm{~W} / \mathrm{m}^{2}-\mathrm{NDC}$ scenario and by over $30 \%$ in the $2.8 \mathrm{~W} / \mathrm{m}^{2}-\mathrm{NDC}$ bridge and $2.8 \mathrm{~W} / \mathrm{m}^{2}-2020$ action scenarios by 2030, compared to the current policies scenario (see also Online Resource Fig. S.2). By 2050, the smaller short-term emission reductions in the $2.8 \mathrm{~W} / \mathrm{m}^{2}-N D C$ scenario are starting to be compensated, with total emission reductions of $73 \%$ relative to the current policies scenario, compared to $77 \%$ under $2.8 \mathrm{~W} / \mathrm{m}^{2}-\mathrm{NDC}$ bridge and $2.8 \mathrm{~W} / \mathrm{m}^{2}-2020$ action.

Although all sectors contributed to reducing GHG emissions, the power sector showed the largest reductions between 2020/2030 and 2050, as this sector is assumed to have the largest potential to reduce emissions by changing the power mix (from fossil fuels to renewables, nuclear, and fossil fuels/biomass with CCS; see Fig. S.3). The power sector is projected to be fully decarbonised before 2050 under all $2.8 \mathrm{~W} / \mathrm{m}^{2}$ scenarios, but decarbonisation took place at a higher rate under $2.8 \mathrm{~W} / \mathrm{m}^{2}-N D C$ than under $2.8 \mathrm{~W} / \mathrm{m}^{2}-N D C$ bridge to compensate for the delay in optimal mitigation. Early retirement of existing coal-fired power plants was required in all $2.8 \mathrm{~W} / \mathrm{m}^{2}$ scenarios, but especially in the $2.8 \mathrm{~W} / \mathrm{m}^{2}-N D C$ scenario (as discussed further in Section 3.2). Reductions in the industry sector were related to reduced energy intensity, most notably in steel production. Most emission reductions in the building sector were achieved through efficiency improvements in space heating, space cooling, and household appliances. 


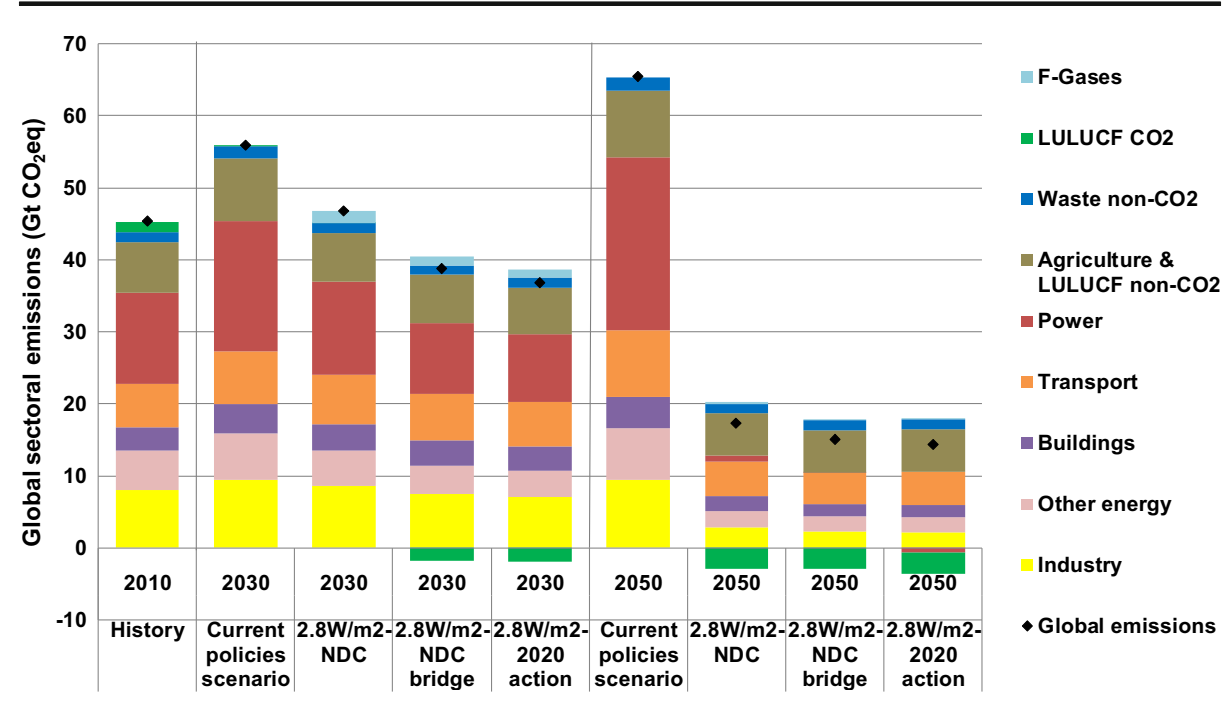

Fig. 2 Global GHG emissions $\left(\mathrm{GtCO}_{2} \mathrm{eq}\right)$ in 2010, 2030 and 2050 per sector and scenario. LULUCF: land use, land-use change and forestry. The category 'Other energy' consists of energy $\mathrm{CO}_{2}$ emissions in other sectors than transport, power, industry and buildings, as well as energy non- $\mathrm{CO}_{2}$ emissions

These efficiency improvements resulted in lower electricity use and final energy intensity of GDP. In the transport sector, electrification played a large role in reducing emissions.

Land-use $\mathrm{CO}_{2}$ emissions were projected to decrease strongly as well, turning negative between 2020 and 2030. Reductions in land-use $\mathrm{CO}_{2}$ emissions resulted from enhanced $\mathrm{CO}_{2}$ uptake by forests due to afforestation and reforestation, and decreased $\mathrm{CO}_{2}$ emissions due to reduced deforestation. Non- $\mathrm{CO}_{2}$ emission reductions between 2020 and 2050 in the $2.8 \mathrm{~W} / \mathrm{m}^{2}$ scenarios mainly came from reductions in energy-related $\mathrm{CH}_{4}$ and F-gas emissions. F-gases and energy-related $\mathrm{N}_{2} \mathrm{O}$ and $\mathrm{CH}_{4}$ emissions ('Other energy' in Fig. 2) showed the strongest relative reductions, both between 2020 and 2050 and against the current policies scenario in 2050. Reducing agricultural non- $\mathrm{CO}_{2}$ emissions is assumed to be challenging, as the $2.8 \mathrm{~W} / \mathrm{m}^{2}$ scenarios showed only minor reductions in this category (Fig. 2).

\subsection{Effects on the global energy system}

Under the $2.8 \mathrm{~W} / \mathrm{m}^{2}-N D C$ scenario, primary energy use is projected to be $9 \%$ lower than under the current policies scenario by 2030, while under the $2.8 \mathrm{~W} / \mathrm{m}^{2}-\mathrm{NDC}$ bridge and $2.8 \mathrm{~W} / \mathrm{m}^{2}$ 2020 action scenarios, the reduction is about 17 to $20 \%$. The $2.8 \mathrm{~W} / \mathrm{m}^{2}-N D C$ scenario showed the largest reductions in primary energy use between 2030 and 2050: $16 \%$, versus only $5 \%$ in $2.8 \mathrm{~W} / \mathrm{m}^{2}-2020$ action and $7 \%$ in $2.8 \mathrm{~W} / \mathrm{m}^{2}-\mathrm{NDC}$ bridge (Fig. 3). The reductions in the $2.8 \mathrm{~W} /$ $\mathrm{m}^{2}$-NDC scenario were mostly realised by rapidly scaling down the use of coal without CCS, which helped compensate for the smaller reduction in energy use until 2030. Penetration of non-biomass renewables is similar in all $2.8 \mathrm{~W} / \mathrm{m}^{2}$ scenarios by 2050 , as the $2.8 \mathrm{~W} / \mathrm{m}^{2}-N D C$ scenario already includes quite a lot of non-biomass renewables in 2030. In the current policies scenario, in contrast, primary energy use is projected to increase further towards 2050, including the use of fossil fuels without CCS.

Under the $2.8 \mathrm{~W} / \mathrm{m}^{2}-N D C$ scenario, electricity demand is projected to be $7 \%$ lower than under the current policies scenario by 2030 , while under the $2.8 \mathrm{~W} / \mathrm{m}^{2}-N D C$ bridge and 


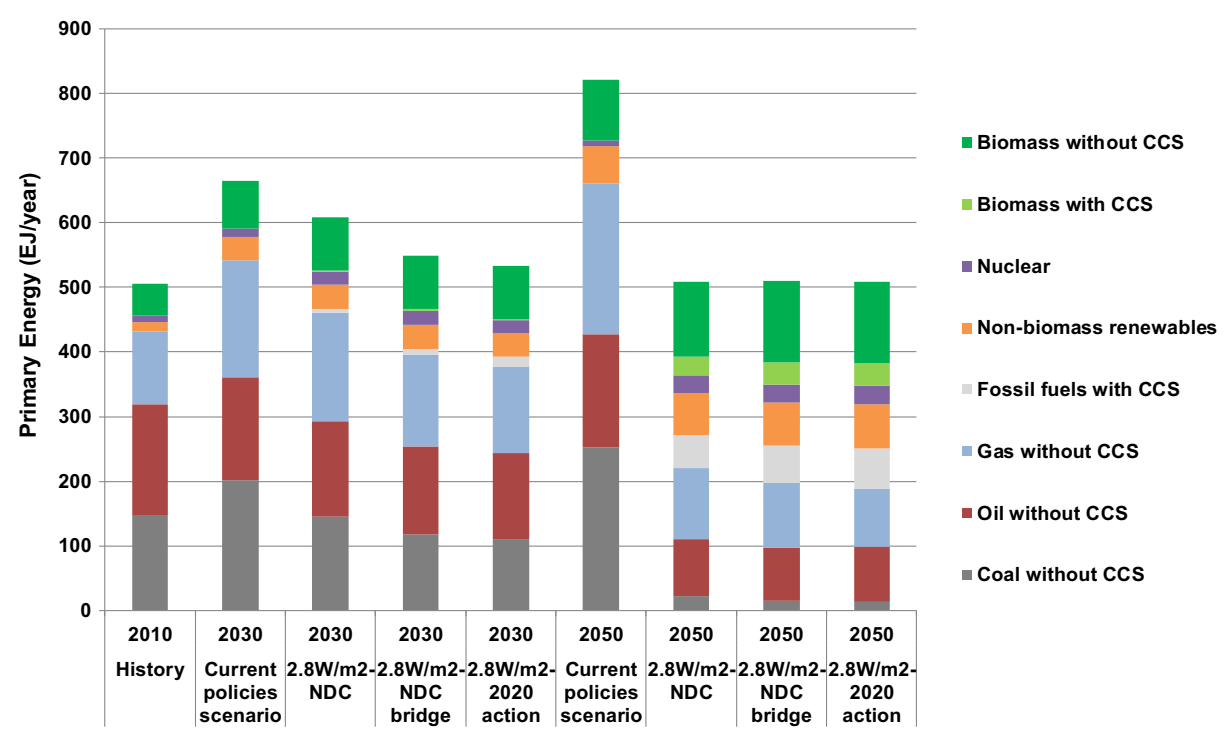

Fig. 3 Global primary energy use (EJ/year) in 2010, 2030 and 2050 in the current policies scenario and the $2.8 \mathrm{~W} / \mathrm{m}^{2}$ scenarios $\left(2.8 \mathrm{~W} / \mathrm{m}^{2}-N D C, 2.8 \mathrm{~W} / \mathrm{m}^{2}-N D C\right.$ bridge, and $2.8 \mathrm{~W} / \mathrm{m}^{2}-2020$ action $)$. Non-biomass renewables are solar energy, wind energy, hydropower, and geothermal energy. CCS carbon capture and storage

$2.8 \mathrm{~W} / \mathrm{m}^{2}-2020$ action scenarios, the reduction is about 15 to $18 \%$. By 2050 , electricity demand in all $2.8 \mathrm{~W} / \mathrm{m}^{2}$ scenarios is projected to be approximately $30 \%$ lower than under the current policies scenario, which indicates that by 2050 , the delayed $2.8 \mathrm{~W} / \mathrm{m}^{2}$ scenarios have caught up with the $2.8 \mathrm{~W} / \mathrm{m}^{2}-2020$ action scenario. Energy savings, measured as the difference in secondary energy use between the $2.8 \mathrm{~W} / \mathrm{m}^{2}$ scenarios and the current policies scenario, are $16 \%$ for $2.8 \mathrm{~W} / \mathrm{m}^{2}-2020$ action, $13 \%$ for $2.8 \mathrm{~W} / \mathrm{m}^{2}-\mathrm{NDC}$ bridge, and $6 \%$ for $2.8 \mathrm{~W} / \mathrm{m}^{2}-N D C$ in 2030 , and around $35 \%\left(2.8 \mathrm{~W} / \mathrm{m}^{2}-2020\right.$ action and $2.8 \mathrm{~W} / \mathrm{m}^{2}-\mathrm{NDC}$ bridge ) and $34 \%\left(2.8 \mathrm{~W} / \mathrm{m}^{2}-\mathrm{NDC}\right)$ in 2050 .

The $2.8 \mathrm{~W} / \mathrm{m}^{2}$ scenarios resulted in lower total installed electricity capacity compared to the current policies scenario, approximately 4 to $10 \%$ in 2030 and 16 to $21 \%$ in 2050 . Coal capacity is projected to be phased out starting in 2036 and before 2070 due to the increasing price of carbon in the $2.8 \mathrm{~W} / \mathrm{m}^{2}$ scenarios (electricity production based on coal is phased out earlier, around 2050). From $2025\left(2.8 \mathrm{~W} / \mathrm{m}^{2}-2020\right.$ action $)$ to $2029\left(2.8 \mathrm{~W} / \mathrm{m}^{2}-\mathrm{NDC}\right)$ onwards, no investment in new plants occurs. In addition, early retirement of existing capacity contributes to the decline of coal capacity from $2036\left(2.8 \mathrm{~W} / \mathrm{m}^{2}-2020\right.$ action $)$ to $2040\left(2.8 \mathrm{~W} / \mathrm{m}^{2}-\mathrm{NDC}\right)$ onwards, driven by the carbon price. Under the $2.8 \mathrm{~W} / \mathrm{m}^{2}-N D C$ bridge scenario, almost all existing coal-fired power plant capacity is projected to be phased out between 2030 and 2060. The $2.8 \mathrm{~W} / \mathrm{m}^{2}-N D C$ scenario required a faster transition: phase-out of coal-fired power plants started about 5 years later than under $2.8 \mathrm{~W} / \mathrm{m}^{2}-\mathrm{NDC}$ bridge, but took place over a shorter period (Fig. 4 and Online Resource Fig. S.4). After coal, electricity production based on gas is projected to be phased out, with some gas capacity remaining as backup. In contrast, the installed power capacity of renewable energy is projected to increase between now and 2050 (Fig. 4), with larger increases, also after 2050 , for $2.8 \mathrm{~W} / \mathrm{m}^{2}-N D C$ than for $2.8 \mathrm{~W} / \mathrm{m}^{2}-N D C$ bridge. As a result of these early retirements and the increased use of renewable energy sources, the share of fossil fuels (coal, oil, and natural gas) without CCS in primary energy supply is projected to be reduced considerably in the $2.8 \mathrm{~W} / \mathrm{m}^{2}$ scenarios, from $85 \%$ in 2010 to $37-43 \%$ in 2050 . 

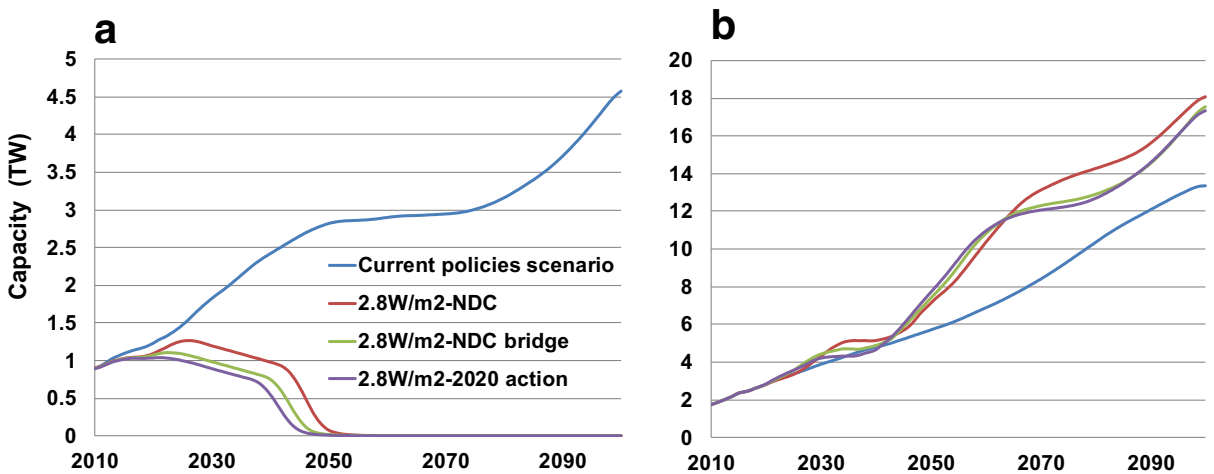

Fig. 4 Installed power capacity (TW) between 2010 and 2100 in the current policies scenario and the $2.8 \mathrm{~W} / \mathrm{m}^{2}$ scenarios $\left(2.8 \mathrm{~W} / \mathrm{m}^{2}-N D C, 2.8 \mathrm{~W} / \mathrm{m}^{2}-N D C\right.$ bridge, and $2.8 \mathrm{~W} / \mathrm{m}^{2}-2020$ action $)$. Panel a coal without CCS, panel b renewables and nuclear

The mitigation scenarios relied on the availability of all possible technologies, especially on energy efficiency improvements and negative emissions from the land use, energy, and industry sectors. CCS was deployed to reach negative emissions in the energy and industry sectors, but it only started playing a significant role after 2050. The share of CCS (used with biomass and fossil fuels) is projected to increase from $0 \%$ of total electricity production in 2010 to approximately $13-18 \%$ in 2050 under the $2.8 \mathrm{~W} / \mathrm{m}^{2}$ scenarios, with BECCS taking up $7-8 \%$ of total electricity production (Online Resource Fig. S.3). Also the share of nuclear is projected to increase after 2020 , reaching $5.5 \%\left(2.8 \mathrm{~W} / \mathrm{m}^{2}-2020\right.$ action $)$ to $5.6 \%\left(2.8 \mathrm{~W} / \mathrm{m}^{2}\right.$ $N D C)$ of total primary energy use and $21 \%\left(2.8 \mathrm{~W} / \mathrm{m}^{2}-2020\right.$ action $)$ to $23 \%\left(2.8 \mathrm{~W} / \mathrm{m}^{2}-\mathrm{NDC}\right)$ of electricity production by 2050 .

In the near term, the share of renewables and low-carbon energy sources ${ }^{3}$ in primary energy use in the $2.8 \mathrm{~W} / \mathrm{m}^{2}$ scenarios (23-26\% in 2030) is projected to be only slightly higher than in the current policies scenario (18\%) (Online Resource Table S.2). In the long-term, however, the energy system shows a complete transformation with the share of low-carbon energy sources in primary energy supply increasing from $15 \%$ currently to $61-63 \%$ by 2050 and further increasing afterwards in the $2.8 \mathrm{~W} / \mathrm{m}^{2}-2020$ action and $2.8 \mathrm{~W} / \mathrm{m}^{2}-\mathrm{NDC}$ bridge scenarios. The $2.8 \mathrm{~W} / \mathrm{m}^{2}-\mathrm{NDC}$ scenario catches up in the second half of the century, reaching $57 \%$ by 2050 and the highest installed renewable power capacity of all scenarios after 2050 (Fig. 4), with extra wind, solar and nuclear capacity going into operation around 2050. The shares of low-carbon energy sources in power supply are even higher, due to a phase-out of fossil fuels without CCS and increased investments in renewable energy. Solar PV, wind, hydropower and nuclear are responsible for about three-quarters of global power supply by 2050 under the mitigation scenarios. The remainder is approximately equally divided between fossil fuels with CCS and BECCS.

\subsection{Effects on global costs}

The implementation of climate policies, pledges, and NDCs in the $2.8 \mathrm{~W} / \mathrm{m}^{2}$ scenarios is projected to significantly reduce GHG emissions and energy use, but this comes with additional costs. As a metric of costs, annual abatement costs expressed as percentage of GDP were used. The annual abatement costs are projected to be high early in the $2.8 \mathrm{~W} / \mathrm{m}^{2}-2020$ action scenario,

\footnotetext{
${ }^{3}$ Biomass with and without CCS, nuclear, non-biomass renewables, and oil, coal, and gas with CCS
} 
but these are compensated by lower costs than the other scenarios later on in the century (Online Resource Fig. S.5). While the $2.8 \mathrm{~W} / \mathrm{m}^{2}-N D C$ scenario is projected to lead to lower costs in the short term, its annual abatement costs are the highest of all scenarios from 2050 onwards. The $2.8 \mathrm{~W} / \mathrm{m}^{2}-N D C$ bridge scenario resulted in costs similar to the $2.8 \mathrm{~W} / \mathrm{m}^{2}-2020$ action scenario, with slightly lower costs until 2035. Costs are very similar across scenarios by 2025 , because even though the reductions in the $2.8 \mathrm{~W} / \mathrm{m}^{2}-2020$ action scenario are higher, these reductions are assumed to be implemented cost-optimally over regions. In the other scenarios, every region has a different carbon price level to achieve their NDCs domestically, which leads to higher global costs per ton of GHG emissions reduced. Cumulative abatement costs are projected to be highest in the $2.8 \mathrm{~W} / \mathrm{m}^{2}-\mathrm{NDC}$ scenario, being $18 \%$ higher than cumulative costs of the $2.8 \mathrm{~W} / \mathrm{m}^{2}-2020$ action scenario in the 2010-2100 period (with a 5\% discount rate; Fig. S.5). The scenario that delays action thus resulted in both higher annual abatement costs in the long run and higher cumulative abatement costs, compared to a scenario that takes early action.

\section{Discussion and conclusions}

This study assessed the long-term impacts of the NDCs and the effect of enhancing their mitigation ambition on changes in energy systems and the level of mitigation costs in achieving $2{ }^{\circ} \mathrm{C}$ emission pathways $\left(2.8 \mathrm{~W} / \mathrm{m}^{2}\right.$ radiative forcing target; about a two third chance of holding warming to below $2{ }^{\circ} \mathrm{C}$ ). In the $2.8 \mathrm{~W} / \mathrm{m}^{2}$ pathways, GHG emission reductions between 2020 and 2050 mainly came from reductions in energy-related $\mathrm{CO}_{2}$ emissions. These emission reductions in the energy system were achieved by a combination of enhancing efficiency and scaling down the use of fossil fuels (no investment in new plants and early retirement of existing capacity), while increasing deployment of low-carbon energy sources.

The results are relevant in light of the review mechanisms and instruments to enhance mitigation ambition included in the Paris Agreement. Our results confirm findings of earlier studies, based on more abstract representations of current policies and pledges, that achieving the $2{ }^{\circ} \mathrm{C}$ target is possible under scenarios that delay optimal mitigation if fast emission reduction are realised after 2020 (Kriegler et al. 2013a; Riahi et al. 2013; Tavoni et al. 2015). Projected 2050 emissions resulting from the $2.8 \mathrm{~W} / \mathrm{m}^{2}$ scenarios are in line with other estimates, such as Riahi et al. (2013), who reported $18-28 \mathrm{GtCO}_{2} \mathrm{e}$ by 2050 for scenarios that assumed pledges emission levels in 2020 and delayed action until 2030. The range in emission projections resulting from the $2.8 \mathrm{~W} / \mathrm{m}^{2}$ scenarios is further in line with the $40-70 \%$ emission reduction on 2010 levels by 2050 globally, as reported by the IPCC for RCP 2.6 scenarios $^{4}$ (IPCC 2014).

Differences in sectoral emissions are larger between the $2.8 \mathrm{~W} / \mathrm{m}^{2}-N D C$ scenario and the $2.8 \mathrm{~W} / \mathrm{m}^{2}-N D C$ bridge scenario than between the $2.8 \mathrm{~W} / \mathrm{m}^{2}-N D C$ bridge and $2.8 \mathrm{~W} / \mathrm{m}^{2}-2020$ action scenario. This suggests that the effects of a 5-year delay in action between 2020 and 2025 are smaller than the effects of 5-year delay between 2025 and 2030.

The emission reduction rates found for the $2.8 \mathrm{~W} / \mathrm{m}^{2}$ scenarios fall within the range reported in IPCC AR5 $\left(\mathrm{CO}_{2}\right.$ approximately -2 to $-7.5 \%$ per year between 2030 and 2050 for scenarios with 2030 emissions between 50 and $55 \mathrm{GtCO}_{2}$ eq; Clarke et al. 2014). Riahi et al. (2013) reported an average $\mathrm{CO}_{2}$ emission reduction rate of $7 \%$ per year between 2030 and 2050 for a scenario that accounted for a continuation of the

$\overline{{ }^{4} 2.8 \mathrm{~W} / \mathrm{m}^{2} \text { belongs to this category }}\left(2.3-2.9 \mathrm{~W} / \mathrm{m}^{2}\right)$. 
unconditional 2020 pledges towards 2030. The $2.8 \mathrm{~W} / \mathrm{m}^{2}-N D C$ scenario showed comparable $\mathrm{CO}_{2}$ emission reduction rates of $6.4 \%$ per year in that period. The $2.8 \mathrm{~W} / \mathrm{m}^{2}$ scenarios are ambitious compared to historical 20-year average annual emission reduction rates; only in short time periods, rates of 2 and 3\% have been observed and primarily due to economic recessions (Riahi et al. 2013).

The projected emission reduction rates and energy transition may be difficult to accomplish in reality for various reasons. First of all, the modelled energy system transformations depended on the availability of all technologies, including socially debated ones such as biomass or CCS, which are needed to realise negative emissions. The reliance on negative emissions technology in the second half of this century is larger in the $2.8 \mathrm{~W} / \mathrm{m}^{2}-N D C$ scenario than in the other $2.8 \mathrm{~W} / \mathrm{m}^{2}$ scenarios. Social preferences and non-rational behaviour are not included in our model, but these are expected to impact the structure of the energy system and thus global emission projections. These preferences could lead to an acceleration of the energy system transition in specific sectors (e.g. electric transport or residential solar), but also to lock-in in conventional systems in other sectors, resulting in a delay and a lower probability of meeting the Paris Agreement's $2{ }^{\circ} \mathrm{C}$ goal. Especially social resistance against the use of biomass (in light of food security or biodiversity) and CCS, as well as investors' resistance to early retirements of power plants, could decrease the probability of meeting the $2{ }^{\circ} \mathrm{C}$ goal in practice. Second, the rapid emission reductions shown by the model may be difficult to realise due to political and institutional inertia. It should be noted that also different assumptions on the main drivers of technology change may play a role (see also Gerlagh et al. 2009 and van Vuuren et al. 2004 for a discussion of optimal timing of climate policy). To account for these factors, an analysis of the transitions at the country level would be an interesting topic for future research (e.g. van Sluisveld et al. 2013).

Given these considerations, the following conclusion can be drawn.

Enhancing the ambition level of NDCs before 2030 can allow for a smoother energy system transition, with lower annual emission reduction rates $(4.5 \%$ instead of $4.7 \%$ between 2030 and 2050) and more time to phase out unabated fossil fuels. It can further result in lower total mitigation costs for meeting the $2.8 \mathrm{~W} / \mathrm{m}^{2}$ target. Implementing no further GHG emission reductions by 2030 than currently formulated NDC reductions would require very rapid reductions after 2030 to meet the $2{ }^{\circ} \mathrm{C}$ target with a chance of about two thirds. The costoptimal pathway towards $2.8 \mathrm{~W} / \mathrm{m}^{2}$ leads to global greenhouse gas emissions of $38 \mathrm{GtCO}_{2} \mathrm{eq}$ by 2030 , a reduction of $20 \%$ on 2010 levels. In contrast, the NDCs are projected to lead to 2030 emission levels of $50 \mathrm{GtCO}_{2} \mathrm{eq}$, an increase of $5 \%$ relative to 2010 . The NDC $2.8 \mathrm{~W} / \mathrm{m}^{2}$ scenario delays mitigation and thus requires more rapid transitions after 2030 to meet the $2.8 \mathrm{~W} / \mathrm{m}^{2}$ target.

Acknowledgements The results presented in this paper have been developed as part of a project financed by the European Commission, Directorate General Climate Action (DG CLIMA), under contract to DG CLIMA (Service Contract no. 071303/2011/662342/SER/CLIMA.A4-Renewal (Ares (2013)3407741)). DG CLIMA was involved in study design regarding the set of scenarios to be developed; the authors were responsible for the methodological approach, the model results, data analysis and writing of the paper. We would like to thank Ariane Labat and Miles Perry (both DG CLIMA) for comments.

Open Access This article is distributed under the terms of the Creative Commons Attribution 4.0 International License (http://creativecommons.org/licenses/by/4.0/), which permits unrestricted use, distribution, and reproduction in any medium, provided you give appropriate credit to the original author(s) and the source, provide a link to the Creative Commons license, and indicate if changes were made. 


\section{References}

de Boer HS, van Vuuren DP (2017) Representation of variable renewable energy sources in TIMER, an aggregated energy system simulation model. Energ. Econ. 64:600-611

Böttcher H, Gusti M, Mosnier A, Havlik P (2011) Global forestry emissions projections and abatement costs. Final Report submitted to The Secretary of State of Energy and Climate Change. IIASA, Laxenburg, Austria. http://www.iiasa.ac.at/publication/more_XO-11-051.php

Clarke L, Jiang K, Akimoto K et al (2014) Assessing transformation pathways. In: Edenhofer O, Pichs-Madruga R, Sokona Y et al (eds) Climate change 2014: mitigation of climate change. Contribution of working group III to the fifth assessment report of the intergovernmental panel on climate change. Cambridge University Press, Cambridge

Climate Action Tracker (2015) Paris agreement: near-term actions do not match long term purpose- but stage is set to ramp up climate action. Climate Action Tracker Statement. PIK, Climate Analytics, NewClimate, Ecofys. http://climateactiontracker.org/assets/publications/briefing_papers/CAT_COP21_Paris_Agreement statement.pdf. Accessed: 12 December, 2015

den Elzen MGJ, Fekete H, Admiraal A et al (2015) Enhanced policy scenarios for major emitting countries. Analysis of current and planned climate policies, and selected enhanced mitigation measures. PBL Netherlands Environmental Assessment Agency, The Hague

den Elzen M, Admiraal A, Roelfsema M et al (2016) Contribution of the G20 economies to the global impact of the Paris agreement climate proposals. Clim Chang 137:655-665

Fawcett AA, Iyer GC, Clarke LE et al (2015) Can Paris pledges avert severe climate change? Science 350:1168-1169

Fekete H, Vieweg M, Rocha M, et al. (2013) Analysis of current greenhouse gas emission trends. Climate action tracker. Climate Analytics, Ecofys and the Potsdam Institute for Climate Impact Research (PIK)

Gerlagh R, Kverndokk S, Rosendahl KE (2009) Optimal timing of climate change policy: interaction between carbon taxes and innovation externalities. Environ Resour Econ 43:369-390

Harnisch J, Klaus S, Wartmann S, Rhiemeier JM (2009) Development of F-gas module for TIMER model. Ecofys, Nuremberg

Havlík P, Valin H, Herrero M et al (2014) Climate change mitigation through livestock system transitions. Proc Natl Acad Sci U S A 111:3709-3714

Hof AF, den Elzen MGJ, Roelfsema M (2013) The effect of updated pledges and business-as-usual projections, and new agreed rules on expected global greenhouse gas emissions in 2020. Environ Sci Pol 33:308-319

IPCC (2014) Climate change 2014: mitigation of climate change. Contribution of working group III to the fifth assessment report of the intergovernmental panel on climate change. Cambridge University Press, Cambridge and New York

Jakob M, Luderer G, Steckel J et al (2012) Time to act now? Assessing the costs of delaying climate measures and benefits of early action. Clim Chang 114:79-99

Kindermann G, Obersteiner M, Sohngen B et al (2008) Global cost estimates of reducing carbon emissions through avoided deforestation. Proc Natl Acad Sci U S A 105:10302-10307

Kriegler E, Tavoni M, Aboumahboub T, et al. (2013a) Can we still meet $2^{\circ} \mathrm{C}$ with global climate action? The LIMITS study on implications of Durban Action Platform scenarios. Clim. Chang. Econ. (in press)

Kriegler E, Tavoni M, Aboumahboub $\mathrm{T}$ et al (2013b) What does the $2^{\circ} \mathrm{C}$ target imply for a global climate agreement in 2020? The LIMITS study on Durban platform scenarios. Clim Chang Econ 04:1340008

Kriegler E, Riahi K, Petermann N, et al. (2014a) Assessing pathways toward ambitious climate targets at the global and European levels: a synthesis of results from the AMPERE project. http://ampere-project. eu/web/images/Final_Conference/ampere_synthesis_5-2014-compact.pdf

Kriegler E, Weyant J, Blanford G et al $(2014 \bar{b})$ The role of technology for achieving climate policy objectives: overview of the EMF 27 study on global technology and climate policy strategies. Clim Chang 123:353-367

Lucas P, van Vuuren DP, Olivier JA, den Elzen MGJ (2007) Long-term reduction potential of non-CO2 greenhouse gases. Environ Sci Pol 10:85-103

Luderer G, Bertram C, Calvin K et al (2013a) Implications of weak near-term climate policies on long-term mitigation pathways. Clim Chang:1-14. doi:10.1007/s10584-013-0899-9

Luderer G, Pietzcker RC, Bertram C et al (2013b) Economic mitigation challenges: how further delay closes the door for achieving climate targets. Environ Res Lett 8

Riahi K, Kriegler E, Johnson N et al (2013) Locked into Copenhagen pledges-implications of short-term emission targets for the cost and feasibility of long-term climate goals. Technol Forecast Soc 90:8-23. doi:10.1016/j.techfore.2013.09.016

Roelfsema M, den Elzen MGJ, Höhne N et al (2014) Are major economies on track to achieve their pledges for 2020? An assessment of domestic climate and energy policies. Energy Policy 67:781-796

Rogelj J, McCollum DL, O'Neill BC, Riahi K (2013a) 2020 emissions levels required to limit warming to below $2^{\circ} \mathrm{C}$. Nat. Clim Chang 3:405-412 
Rogelj J, McCollum DL, Reisinger A et al (2013b) Probabilistic cost estimates for climate change mitigation. Nature 493:79-83

Rogelj J, den Elzen M, Höhne N et al (2016) Paris Agreement climate proposals need a boost to keep warming well below $2{ }^{\circ} \mathrm{C}$. Nature 534:631-639

Schwarz W, Gschrey B, Leisewitz A, et al. (2011) Preparatory study for a review of Regulation (EC) No 842/ 2006 on certain fluorinated greenhouse gases. http://ec.europa.eu/clima/policies/f-gas/docs/2011_study_en. pdf, European Commission

van Sluisveld MAE, Gernaat DEHJ, Ashina S et al (2013) A multi-model analysis of post-2020 mitigation efforts of five Majore economies. Clim. Chang. Econ. 04:1340012

Stehfest E, van Vuuren DP, Kram T, Bouwman L (2014) Integrated assessment of global environmental change with IMAGE 3.0. Model description and policy applications. PBL Netherlands Environmental Assessment Agency. http://www.pbl.nl/sites/default/files/cms/PBL-2014-Integrated_Assessment_of_Global_ Environmental_Change_with_IMAGE_30-735.pdf, The Hague

Tavoni M, Kriegler E, Riahi K, van Vuuren DP et al (2015) Post-2020 climate agreements in the major economies assessed in the light of global models. Nat Clim Chang 5:119-126

U.S. EPA (2013) Global mitigation of non-CO2 greenhouse gases: 2010-2030. United States Environmental Protection Agency, Office of Atmospheric Programs. http:/www.epa.gov/climatechange/Downloads/EPAactivities/MAC_ Report_2013.pdf, Washington, DC

UNEP (2013) The Emissions Gap Report 2013. A UNEP Synthesis Report United Nations Environment Programme (UNEP). http://www.unep.org/publications/ebooks/emissionsgap2013/

UNEP (2014) The Emissions Gap report 2014. United Nations Environment Programme (UNEP), Nairobi

UNEP (2015) The Emissions Gap report 2015. United Nations Environment Programme (UNEP), Nairobi

UNFCCC (2009) Copenhagen Accord. http://unfccc.int/resource/docs/2009/cop15/eng/107.pdf

UNFCCC (2010) Decision 1/CP.16, The Cancun Agreements. UNFCCC document FCCC/CP/2010/7/Add.1. http://unfccc.int/resource/docs/2010/cop16/eng/07a01.pdf\#page=2

UNFCCC (2015a) Paris Agreement. Decision 1/CP.17. http://unfccc.int/resource/docs/2015/cop21/eng/109r01. pdf, UNFCCC document FCCC/CP/2015/L.9/Rev.1

UNFCCC (2015b) Intended Nationally Determined Contributions (INDCs). http://www4.unfecc. int/submissions/indc/Submission\%20Pages/submissions.aspx, Accessed: 29 October, 2015

van den Berg M, Hof AF, van Vliet J, van Vuuren DP (2015) Impact of the choice of emission metric on greenhouse gas abatement and costs. Environ Res Lett 10:024001

Vandyck T, Keramidas K, Saveyn B et al (2016) A global stocktake of the Paris pledges: implications for energy systems and economy. Glob Environ Chang 41:46-63

van Vliet J, van den Berg M, Schaeffer M et al (2012) Copenhagen accord pledges imply higher costs for staying below $2^{\circ} \mathrm{C}$ warming. Clim Chang 113:551-561

van Vuuren DP, de Vries B, Eickhout B, Kram T (2004) Responses to technology and taxes in a simulated world. Energ Econ 26:579-601

van Vuuren DP, Stehfest E, Gernaat D, et al. (2016) Energy, land-use and greenhouse gas emissions trajectories under a green growth paradigm. Submitted to Glob. Environ. Chang 